\title{
Design-led Innovation and Circular Economy Practices in Regional Queensland
}

\begin{abstract}
The Circular Economy proposes a sustainable economic model that encourages businesses and governments to work toward the goal of conserving natural resources and reducing waste. This model largely relies on government policies that encourage waste reduction and help businesses creating markets to re-purpose that waste profitably. Design-led innovation offers methods to drive required business model transformation and is recognized as one of the key enablers in the transition to a Circular Economy. It is evident globally that metropolitan cities and countries with high innovation indices are better able to transition to a Circular Economy by applying design-led innovation. Although more populous states and densely populated cities in Australia have started to initiate Circular Economy practices, it is unclear if similar initiatives could be developed in regional economies in Australia and if design-led innovation has a role to play in their acceptance and development. This study is an exploration into two regional areas in the state of Queensland: the Sunshine Coast and North Queensland. The qualitative study explores the views of waste managers of local councils, small scale applications of the Circular Economy on two university campuses and an experiment to introduce a street of business owners to Circular Economy practices.
\end{abstract}

Key Words: Circular Economy, Design-led innovation, Service Design Thinking, North Queensland, Sunshine Coast, Regional Queensland

\section{Introduction}

The Circular Economy is gaining momentum among policy makers as a way to achieve a sustainable economic future that reduces waste, increases product reliability, and saves natural resources. The Circular Economy envisions breaking out of what is seen globally as the wasteful practice of large-scale exploitation of scarce natural resources and planned obsolescence of products that feed an unsustainable system of cheap consumer credit and endless growth (European Commission, 2012; Ellen MacArthur Foundation, 2015a). The amount of waste generated by the world continues to increase at alarming rates, making achieving international targets to reduce greenhouse gas emissions unlikely unless there is a major paradigm shift in reducing waste. The 2019 Circularity Gap Report (Circle Economy, 2019) maintains that the only way to meet the Paris Agreement greenhouse gas reduction targets is putting Circular Economy practices into place. The UN Environment International Resource Panel (2019) reports that current natural resource use could double by 2050 unless action is taken. The waste products from this accelerating consumption is creating environmental catastrophes, such as tons of plastic circulating in the world's oceans, killing marine life and entering the global food chain as microplastics (Jambeck et al., 2015).

The Circular Economy is growing greater acceptance by governments as a viable model to slow down pollution in the world's air and water and manage dwindling natural resources without sacrificing business profit. The Circular Economy model replaces the linear economy's Take- 
Make-Use-Dispose process with the Make-Remake-Use-Reuse paradigm. The Circular Economy works on the principle of closed loop systems found in nature, where resources find their equilibrium and recycling and decay act as nutrients. Unlike in nature, however, recycling is at the bottom end of the Circular Economy "nutrient” loop. Essentially, the Circular Economy relies on waste minimisation by promoting longer product life cycles, sharing resources, and re-use and re-manufacturing. Figure 1 visualises the functioning of the Circular Economy in a diagram.

\section{Biological Nutrients}

\section{Technical Nutrients}

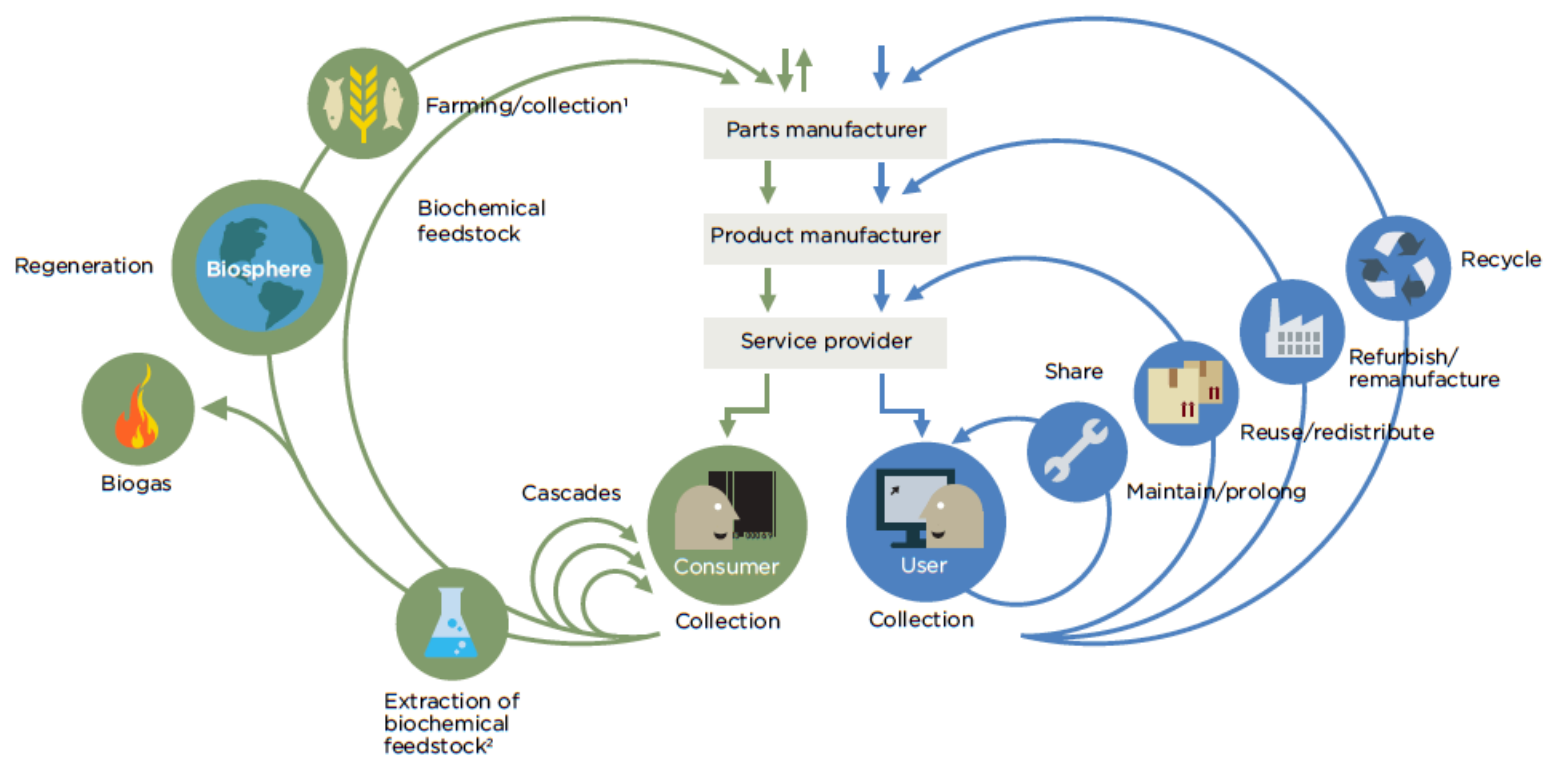

Figure 1. Outline of the Circular Economy (detail) (Ellen MacArthur Foundation et al., 2015a:24)

The circular value chain requires new innovative business models that are based on waste recovery, circular supplies, product life extension, sharing platforms and products as service (Gerholdt, 2015; ZeroWaste, 2016; Kalmykova, Sadagopan and Rosado, 2018). However, businesses are reluctant to engage in Circular Economy practices (Prendeville, Cherim and Bocken, 2018) because the transition is a complex undertaking that requires active participation of myriad stakeholders, including, governments and local councils, product developers and manufacturers, consumers, recyclers, re-manufacturers, and companies that work together to coordinate logistics to minimise waste and re-use raw materials or re-manufacture finished goods.

Because it is a complex re-thinking of waste reduction and resource preservation that involves multiple players along the supply and value chain, the Circular Economy lends itself to the use of design-led innovation methods, which include: Design Thinking or Service Design Thinking with their systematic and human-centred approach, design ideation (mapping), iteration (prototyping), Co-creation and collaboration to facilitate organisational cultural shifts. Design-led innovation offers methods to drive radical innovation and business model transformation based on customercentricity (Design Council, 2015; Prendeville and Bocken, 2016). The use of design-led innovation has a proven record of building competitive advantage for businesses and organisations by creating new methodologies for stakeholder engagement or by facilitating 
organisational structural change (Bucolo, Wrigley and Matthews, 2012; Bucolo and Wrigley, 2014; Gardien, Rincker and Deckers, 2016; Berg et al., 2016). Although the transition from a linear economy to a circular model is still in its early stages (United Nations Economic Commission for Europe, 2018) various toolkits based on design-led methods are already available which help businesses and governments shift their thinking towards Circular Economic practices (e.g. Circular Economy Toolkit - Resources for an Evolving World, Evans et al., 2013).

The crux of making a Circular Economy work relies heavily on how localities, states and countries deal with their waste streams and how governments incent businesses and local governments to reduce landfill dumping. In a national context, Queensland - the subject of this research-lags far behind other states in Australia when it comes to waste re-use and recovery at 44.5\%; South Australia, by contrast, has close to an $80 \%$ re-use and recovery of waste while the national average is 61\% (Queensland Government, 2018a). According to Queensland waste strategists, the state would have to recover an additional 1.5 million tons of waste a year to meet the national average, a reduction which state planners say it is possible to achieve with the right leadership and policy directions from government (Queensland Government, 2018a).

Policy makers may promote the Circular Economy in their strategic waste management visions, but global markets are putting economic pressures on realising their goals, particularly when it comes to recycling. The largest export market for Australian recycled waste has been China, but the Chinese government has stopped accepting recycled materials with higher levels of contamination. China's policy shift has led to a global waste crisis (Parker, 2018), which is also requiring local Australian governments to reduce the amount of recycled waste they accept and seek innovative ways to re-use it locally.

Australia, however, consistently lags behind its international competitors in innovation practices (Palmer et al., 2015; Armitage, 2017; Dayton and Green, 2018) principally because of its small population: 25 million people-mostly living in large urban centres. Australia has a population density of 3.14 people per square kilometre compared to a population density of 32.87 in USA and 143.30 in China. Outside of Brisbane, for example, there are large areas of Queensland with low population densities. Circular business models based on reverse logistics or sharing economy principles might not be profitable in such thinly populated areas. Furthermore, regional areas often have weak innovation systems; institutions that can accelerate innovative change are often underdeveloped or missing (Coronado, Acosta and Fernández, 2008). The regional design industry in Australia, for example, is not always aware about the role they can play as enabler of innovation and driver of regional economic development (Fleischmann, Daniel and Welters, 2017).

Despite its innovation deficit, Australia has a great deal to gain economically from implementing a Circular Economy. The World Economic Forum has estimated that a Circular Economy in Australia could be worth $\$ 26$ billion by 2025 (White, 2015). However, Australia is a patchwork of Circular Economy practices largely focused on waste minimisation, although South Australia has quantified the potential economic benefits of a more Circular Economy and has begun large scale Circular Economy initiatives (Green Industries South Australia, 2017). It is unclear if similar initiatives could be developed in regional economies in Australia and if design-led innovation has a role to play in their acceptance and development.

There is a lack of existing research about how the Circular Economy is tracking in regional areas in Australia. This study explores the potential and circular practices in two regional areas in Queensland: the Sunshine Coast and North Queensland. The two regions represent a remote area of the state and one that is a fast growing centre closer to the state's capital, Brisbane. The 
qualitative study, based on in-depth interviews, explores the views of waste managers of local councils in these two regions toward Circular Economy practices and examines if design-led innovation is playing a role in transitioning to those practices. The investigation also focuses on small scale applications of the Circular Economy on two university campuses and bottom-up initiatives such as an experiment to introduce a street of small business owners to Circular Economy practices.

\section{The Circular Economy in Europe and Australia: Policy as Driver}

The benefits of transitioning business and consumer practices to the Circular Economy do not solely represent a "feel good" opportunity but have reported tangible economic benefits including large scale business opportunities. In London, for example, predictions are that the transition to a Circular Economy could create 40,000 new jobs by 2030 and reduce unemployment in the city by 12\% (WRAP and Green Alliance, 2015). The European Union (EU) has been actively putting legislative teeth into making the Circular Economy a reality, spurred by predictions that circular practices could be worth 1.8 Trillion Euro and increase GDP by 7\% (Ellen MacArthur Foundation, 2015a). Starting in 2008, the EU Parliament began approving a number of initiatives to reduce waste like plastics and packaging (European Commission, 2016). Some EU member states are implementing large scale waste minimisation programs and achieving immediate economic benefits. These EU countries have ambitious goals to reach equilibrium between waste and use (Braw, 2014). Denmark, for example, is aiming at recycling 50\% of all household waste by 2022. A Green Transition Fund is used for 'creating industrial symbiosis where one company's waste is another company's resource' and a new law bans the construction of new incineration plants (Braw, 2014). One of the central tenets of the Circular Economy is lengthening product life cycles using repair and re-furbishing. Sweden, for example, is trying to encourage repairs by halving its VAT tax on repair work to $12 \%$ instead of the current $25 \%$ (European Environment Agency, 2017).

In comparison, Australia has few laws enforcing product reliability and re-use. However, there are some state-wide initiatives in Australia that make use of food waste. South Australia's Glenelg water treatment plant, for example, uses food by-products to augment its power requirements. The South Australian government is also developing a bioenergy roadmap to link biomass suppliers in regions to users of energy (Jacobs, 2015) and is predicting that a Circular Economy will reduce greenhouse gas emissions by more than $27 \%$ by 2030 (Green Industries South Australia, 2017). In Victoria, the Aurora Sewage Treatment plant north of Melbourne is also operating a co-digestion facility where 100 cubic metres of food waste sourced from markets and food manufacturers is used daily to help power the treatment plant. Victoria is also offering Advanced Organics Processing Technology Grants to encourage the development of small-scale anaerobic digestion technology to process organic waste (Australian Water Association, 2016). In New South Wales, the largest scale use of food waste as an energy source and fertilizer is being rolled out in Cowra, a country Australian town on the Lachlan River. At full capacity, government sponsors of the initiative predict $60 \%$ of Cowra's energy will come from biomass processing. A New South Wales grant is helping fund the Cowra project (embark, 2016).

The Circular Economy in South Australia has the potential to create 25,700 new full-time equivalent jobs by 2030 (Green Industries South Australia, 2017). In a white paper the Queensland Government also predicts job creation and business opportunities by implementing Circular Economy practices in the handling of waste (Queensland Government, 2018a). The state's current waste reduction initiatives include the re-introduction of a waste levy; the banning of lightweight plastic shopping bags on 1 July 2018, which has met with consumer resistance; the introduction of a container refund scheme; engaging partners to improve handling of organic 
wastes and the development of a Plastic Pollution Reduction Plan (Queensland Government, 2018b). However, these initiatives will only eventuate if smart regulation incents private-sector leadership and businesses share data and collaborate (Preston, 2012; United Nations Economic Commission for Europe, 2018).

Examples of Circular Economy initiatives can often be found in large metro areas because of logistical considerations and abundant resources. Australia exemplifies the importance of cities to drive the Circular Economy, particularly with its high population concentrations in metropolitan areas, geographic isolation and small manufacturing sector. The sharing economy-involving ride sharing and food distribution-is taking root within Australian cities (Collett, 2018); automation is also now part of the Circular Economy. Melbourne, which accounts for about 20\% of Australia's population has been piloting smart bins that compact rubbish and have solar-powered censors that alert city waste managers when the bins are $70 \%$ full so they can be emptied. The idea is to keep the city clean, so it is attractive to tourists (City of Melbourne, 2015).

On a smaller scale, the Lismore City Council in New South Wales has funded an active certifiedorganic composting project that supplies farms and gardens with nutrient-rich BIOcycle compost (Northern Rivers Waste, 2018). The Lismore City Council has also experimented with a re-use process to turn recycled glass into sand that can be used in construction and roadworks by local construction businesses (Turnbull and MacKenzie, 2017).

These independent initiatives illustrate a local willingness in Australia to experiment with reducing waste streams and to engage in Circular Economy practices. Design-led innovation may be a bridge from policy to Circular Economy practice but there are currently strong international headwinds affecting Circular Economy waste management practices globally, and they centre on China's new policies about accepting recycled waste from abroad.

\section{Global Complexities: China’s Changing Waste Acceptance Policy}

China's influence in the development of the Circular Economy is instrumental in governing the profitability of companies that further re-process and consolidate waste purchased from local governments. China has introduced lower rates of contamination of recycled waste it accepts from abroad and has stopped importing certain categories of waste. The negative impact globally has sent shockwaves through recycling businesses that rely on the Chinese market. The UK, for example, had been sending to China about half a million tonnes of plastics and 1.4 million tonnes of recovered paper annually (Cole, 2017). For Australian recyclers, China has been the major market offshoring the country's waste. In 2016-2017 Australia sent 1,25 million tonnes of recycled materials to China but that export market has been threatened by China's National Sword program, which began to limit solid waste it would accept starting in January of 2018 (Lasker and Goloubeva, 2018). The embargoed waste included plastics, unsorted waste paper and textile materials. In March of 2018 China also adopted strict contamination thresholds of $0.5 \%$ of the waste it would continue to accept from foreign suppliers. Contamination means waste that contains unwanted materials. The current global standard is $1.5 \%$ waste contamination. At stake is billions of dollars of offshore business for Australia's waste industry. One report in Australia says many recyclers are in danger of going broke because of a global price collapse triggered by China's decision to ban imports of contaminated recycling material (Chang, 2018). New South Wales and Victoria have provided rescue packages to prop up the industry in the short term (EPA NSW, 2018) However, there are concerns that recycling companies that buy their materials from local councils will stop paying for them, forcing rate payers to pay for ongoing recycling. 


\section{Design-led Innovation in a Circular Economy: A Tool for Waste Managers?}

China's new restrictions may encourage waste managers to look at design-led innovation as a key to developing new ways to handle waste streams. Design has become an important driver of economic innovation and better living globally. Design has evolved from a style-driven focus to a creative paradigm for problem solving in highly technical fields like science and engineering and social areas (Commission of the European Communities, 2009; Design Council, 2011; Fleischmann, 2013; Bucolo and Wrigley, 2014; DesignSingapore Council, 2016). Governments have taken notice of the elasticity of design creativity and are funding initiatives to incorporate design into economic planning and organisational change (Raulik, Cawood and Larsen, 2008; Raulik-Murphy, 2010; Gulari, et al., 2017). Developed countries have used design as a tool for economic and social development and 'as an asset for their economic advantage' (Raulik, Cawood and Larsen 2008:119).

The Australian Department of Industry, Innovation and Science argues that design-led innovation can help 'businesses from a wide range of industry sectors improve their productivity and competitiveness' (Australian Department of Industry, Innovation and Science, 2016). In practical terms, design-led innovation can drive business performance and help develop innovation capabilities through the development of new products, services and business models using methods that are central to the design discipline. A well-known application of design-led innovation is Design Thinking which has been globally adopted by businesses to drive radical innovation, create competitive advantages and change business culture and behaviour (Brown, 2009; Liedtke and Ogilvie, 2011; Bucolo, Wrigley and Matthews, 2012).

Design-led innovation is recognized as one of the key enablers in the transition to a Circular Economy (Ellen MacArthur Foundation, 2013; RSA - Action and Research Centre, 2016; Barbero and Bicocca, 2017). According to Wastling, Charnley and Moreno (2018:3) 'there is a growing body of research outlining the role of design in a Circular Economy and suggesting useful frameworks, tools and strategies for implementing circular design principles'. Andrews (2015:312) argues that designers 'have the opportunity to lead the paradigm shift and in addition to designing for the "closed loop" they have the potential to influence business and consumer behaviour'.

Existing literature which examines the role of designers in the transition to a Circular Economy has mainly focused on responsible and sustainable product design (e.g. Mestre and Cooper, 2017; den Hollander, Bakker and Hultink, 2017) including in the fashion and textile industry which has begun re-using materials that were often recycled (e.g. Moorhouse and Moorhouse, 2017; Smith, Baille and McHattie, 2017; Goldsworthy, 2017). Various authors highlight that designers need to change their thinking and consider the whole lifecycle of products before even starting to design (Andrews, 2015; Ceschin and Gaziulusoy, 2016; European Environment Agency, 2017).

Virtanen, Manskinen and Eerola (2017) argue that a new kind of design thinking is required that considers the circularity of product parts and materials. An example of such new design thinking is Nike's "Reuse-a-Shoe” program. This closed-loop recycling program recovers materials through the collection of old sports shoes which are ground up and then turned into surfaces for playgrounds, running tracks and walkways-a product called Nike Grind (www.nikegrind.com). This circular business model takes advantage of down-cycling which turns 'materials from one or more used products into a new product with lower quality' (Forum for the Future, 2016:10).

There is an increasing interest in recycled material driven design. Various waste streams such as demolition waste or natural products are the source of innovation (e.g. see Marchese, 2017). In 
the Lahti region in southern Finland-a regional centre with 200,000 residents and an economy mainly built on small and medium-sized enterprises (SMEs)-a Circular Material Library helps local businesses use recycled materials in support of industrial symbiosis (Virtanen, Manskinen and Eerola, 2017). However, designers and manufacturers have to be aware of the total value chain process which they can achieve through mapping processes.

Philips has introduced a number of products based on Circular Economy principles, for example, its pay-per-lux and refurbishment of medical equipment (Philips Lighting, 2015; Kane, 2016).

For Philips, design-led innovation involves rapid prototype testing and using a co-creation experience process because it is impossible to understand the whole ecosystem upfront and topdown (Sanders and Stappers, 2008; Gardien, Rincker and Deckers, 2016; Fleischmann, Hielscher and Merritt, 2016).

Service Design Thinking drives initiatives such as those by Philips in helping businesses, organisations and governments to capture value and achieve sustainable competitiveness. Service Design tools such as service ecology mapping, stakeholder motivation matrixes and empathy maps have been identified as useful for servitization and particularly in the early stages of business model innovation (Simonchik et al., 2015; West and Nardo, 2016). Making use of such tools, Australia Post (2017) co-designed for innovation with Nespresso and developed a reverse logistics system where customers can use a pre-paid (\$1.90) envelope to send 130 used aluminium capsules (which cannot be recycled through domestic bins) directly to a recycling plant. The waste is separated into the residual coffee used for composting and capsules are recycled into new aluminium products.

Various design-led toolkits have been developed to help transition to circular thinking. For example, the Ellen MacArthur Foundation has collaborated with IDEO (a world-renowned design and innovation company) and developed "The Circular Design Guide" (2017) which offers circular innovation methods, creative exercises/worksheets, and links to hands-on tools. The Foundation also offers a toolkit for policy makers which was trialled by Denmark (Ellen MacArthur Foundation, 2015b). Initial research of the effectiveness of "The Circular Design Guide” by Reigado et al. (2017) found its strength was to engage businesses in the early phases of understanding and developing the change from linear to circular activities and to improve the application of product-service-systems methodologies.

It is evident from examples in the literature that metropolitan cities and countries with high global innovation indices such as Switzerland, the Netherlands, Sweden and the UK (Global Innovation Index, 2018) are most advanced in transitioning to a Circular Economy. Although more populous states and densely populated cities in Australia have started to initiate Circular Economy practices, less is known about regional areas and if design-led innovation has a role to play in the development of circular thinking.

\section{Northern Australia and Southeast Queensland First Steps Investigating Circular Economy Activities: Methodology}

In order to gain first insights into Circular Economy activities and the use of design-led innovation as enabler of such activities in regional Australia, two regions in Queensland were investigated. Queensland is the $3^{\text {rd }}$ largest state in Australia with a population of 4.9 million.

A case study approach (Yin, 2009) was used in which the same phenomenon was explored in two cases using the qualitative method of in-depth interviews. Because Circular Economy practices are a new phenomenon globally, using case study research was deemed appropriate; this approach 
is often used to understand a new issue in its real-life context (Yin, 2009) and is considered particularly useful for the early, exploratory stage of a study (Rowley, 2002).

Case one examines the North Queensland region, focusing on its largest cities, Townsville and Cairns. Case two focuses on Southeast Queensland's Sunshine Coast which is one of the fastest growing regions in Queensland. These regions were selected due to their similarities: population size; waste is managed through the local councils (Townsville City Council, Cairns Regional Council, Sunshine Coast Council); and both regions have a regional university (James Cook University, University of the Sunshine Coast) as vital sources of research and innovation that flow into regional development. The two regions, however, differ considerably in their geographic isolation-Townsville is located $1300 \mathrm{~km}$ north of the state capital Brisbane and $350 \mathrm{~km}$ south of the next major city Cairns. The Sunshine Coast region is only $100 \mathrm{~km}$ north of Brisbane.

The Sunshine Coast, Cairns and Townsville are part of a network of 77 local governments within the state of Queensland that operate their own waste management programs with independent budgets. With a combined population of ca. 307 000, Cairns and Townsville have diverse economies and a population base growing at 2\% over the past 7-10 years. The largest employers are Health Care and Social Assistance, Public Administration and Safety, Accommodation and Food Service, Education and Training, Retail and Construction.

The Sunshine Coast is one of the fastest growing regions of Queensland with a population growing at $10.1 \%$ between 2008-2013. The current population of the Sunshine Coast region is 298,000 and is projected to grow to 470,000 by 2036 (Sunshine Coast Council, 2018). Similar to Townsville and Cairns, the Sunshine Coast economy is driven by the health care profession, construction, retail, education and training, accommodation and food services. At the time this research was conducted, the councils were working under the following waste management strategies: Sunshine Coast Waste Strategy 2015-2025 (Sunshine Coast Council, 2014), Cairns Regional Council Waste Management Strategy 2010-2015 (Cairns Regional Council, 2010) and NQ Regional Waste Reduction \& Recycling Plan 2014- 2024 for Townsville (Townsville City Council, 2014). The Cairns Regional Council has introduced a new Waste Management Strategy 2018-2027 (Cairns Regional Council, 2018) at the time this paper was being written.

Multiple sources of evidence were used (Yin, 2009) to explore the Circular Economy activities and use of design-led innovation methods in the two regions. Three key stakeholder groups were identified: waste managers of local councils as the people who would be most knowledgeable about waste management innovations in their regions; environmental and operation managers at the regional universities who are knowledgeable about innovation and existing links between the university, industry and community; and the third group was identified as initiators of or participants in Circular Economy bottom-up initiatives. The author's personal networks in Townsville were contacted to learn about any Circular Economy initiatives or projects being set up or already running. In case of the Sunshine Coast region, an initiative "The Circular Experiment” (www.thecircularexperiment.com) was discovered through desk research and included in this study.

In total, eleven interviews were conducted: three with waste managers of the Townsville City Council, Cairns Regional Council and the Sunshine Coast Council; and two with environmental and operations manager at James Cook University and the University of the Sunshine Coast. Two interviews were completed with the initiators of the Circular Economy Experiment on the Sunshine Coast who conducted the pilot project involving small businesses on Ocean Street, Maroochydore to explore the potential to implement Circular Economy initiatives. One of these 
interviews was a follow-up interview with one of the initiators and conducted via phone for clarification on the use of design-led innovation in the experiment. Interviews were also conducted with four business owners involved in the project and the Sunshine Coast Council waste manager who liaised with the project. All stakeholders agreed to a face-to-face semistructured conversation which lasted around one hour. Three researchers were involved in conducting the interviews which were recorded and transcribed.

Interviews were designed to ascertain the following: knowledge level and attitudes towards implementing Circular Economy practices and the awareness and use of design-led innovation to enable/support such implementations; the level of advancements in initiating and implementing Circular Economy practices and the role design-led innovation played; and perceived barriers/challenges that currently inhibit potential progression towards a Circular Economy in the region. In the case of interviews with the business owners involved in the Circular Experiment, questions focused on the success of implemented practices and their long-term sustainability. Questions across all stakeholder groups were open-ended to allow respondents to give more indepth responses.

The research was conducted over a period of eight months, which allowed exploration of intentions of the Circular Experiment as well as its outcomes. During research the state legislation and global waste management practices changed: the Queensland government announced the introduction of a waste levy (AUD\$70 per tonne) starting in 2019 (Caldwell, 2018) and China, the world's largest importer of waste, imposed import restrictions and 'stopped taking in 24 types of scraps starting 2018' (Lee, 2018). The interviews with waste managers conducted before and after these changes reflect these dynamic economic developments involving waste management.

Although limited in scope, this study provides valuable first insights into the development of Circular Economy practices in regional Queensland, Australia and the use of design-led innovation methods as enabler of such practices.

\section{The Circular Environment in Townsville and Cairns: Findings on Waste Management}

Both Townsville and Cairns waste management officials are familiar with the Circular Economy and have heard of Design Thinking. Stakeholder consultation was done by both councils when developing their Waste Strategies and they understand the importance of working with businesses and the wider community for better waste handling in the coming decade. It is clear from the interviews that waste managers encourage waste avoidance strategies, but they are not sure about their role in a Circular Economy. Cairns operates five waste and transfer stations and Townsville operates six stations. The councils currently contract with a waste company that sorts all its curbside recycling into fifteen usable waste streams. In practice, all actions in Townsville and Cairns are about recycling, which ranks at the bottom of the Circular Economy technical cycle hierarchy. Practices of maintaining/prolonging, reusing/redistributing or refurbishing/ remanufacturing to help reduce or reuse waste have not yet gained traction in either city. At the time of the interview, both Townsville and Cairns governments were waiting for the state to release its new waste management strategy which they hoped would align more with Circular Economy waste and resources management practices. The Townsville waste management official supported stakeholder consultations to generate ideas and strategic direction and also said he was familiar with design-led innovation strategies such as Design Thinking and Service Design Thinking. However, he could not imagine how to apply the concepts in daily business operations. 
Various waste reduction initiatives leaning toward Circular Economy practices are being trailed by the councils. The Townsville City Council is working with a local company Vital Resource Management (VRM) which takes food waste and turns it into fertiliser. Cairns Regional Council has a significant re-use capability in using a Bedminster AWT processor (operated under contract by Suez) which turns organics into mulch and contributes a 30\% reduction of green waste into landfills. In September 2017, the Cairns Regional Council stopped sending e-waste to Townsville; they send it instead to a local Cairns centre called E-Waste Recycling, which recycles TV's, computers, laptops, and printers as part of the Australian government's National Television and Computer Recycling Scheme which began in 2011.

Both councils are keen to develop circular waste management practices. One of the projects trialled in Townsville by the waste company Re.Group is turning recycled glass into sand for use locally in construction as a sand replacement, aggregate replacement or in road bedding. Making these re-use opportunities a reality would require ways to bag and store the re-manufactured material. The Townsville City Council wants to collaborate with the Endeavour Foundation which supports people with intellectual disabilities to employ them to bag the re-use products and sell them to local tool shops. Cairns and Townsville also sell furniture recovered from their landfills. Other opportunities being tabled include a stronger business focus on handling organics, plastics, construction and demolition waste. Townsville is also hoping to cut down on food waste by marketing a smartphone app called "Love Food Hate Waste". This is coupled with an investigation into composting food waste.

There are major factors mitigating Circular Economy practices in North Queensland. The biggest challenge at the time of the interview was that Queensland did not charge a waste levy for using landfills like its neighbouring state, New South Wales. Essentially, there was no local or state government incentive to reduce use of landfills. Conventional thinking is that it is essentially cheaper to throw out products and too expensive to process and transport them due to regional North Queensland's remoteness to markets.

Another challenge identified by the Townsville waste manager is funding from the local council to encourage pilot waste reduction and re-use projects. Currently, the Townsville City Council has an education team within its waste water division but does not fund projects to develop waste processing that would create local employment.

Neither council waste managers use design-led innovation methods despite the fact that both are aware of the Design Thinking method; the reality is there is little understanding of how these methods work and neither manager has formulated a practical approach to implement design-led innovation in their daily operations.

\section{The Sunshine Coast Council's Approach: Findings on Waste Management} Waste management is a growing concern at the Sunshine Coast Council, where population pressures are driving the Council's search for better ways to handle its waste to reduce its landfills. The Sunshine Coast Council operates eight landfill sites and a Materials Recovery Facility to process approximately 300,000 tons of waste a year. An estimated $42 \%$ of that waste is being recovered through a variety of waste reduction strategies, mainly recycling and re-use. The Council's waste stream with the highest recovery rate is concrete from demolition sites, which is reprocessed and sold as an aggregate to be re-used in construction projects. The Materials Recovery Facility processes and sorts household recycling that includes glass, paper and plastic. The Council also operates a garden waste recycling program in 24,000 homes that grinds green waste into mulch, which is either given away or sold. Currently, the Council offers households a 
garden waste bin at a cost of $\$ 60$ per month and about a quarter of the households use them, a use rate which is growing at 5\% per year since it was introduced in 2015.

The Sunshine Coast Council's approach to explore Circular Economy practices contrasts sharply with Townville and Cairns. The Council has a full-time business development manager whose role is to research and develop markets for the Council's waste streams. The Sunshine Coast Council also benefits from its proximity to a major market in Brisbane where waste stream processors are based, making the sale and processing of waste streams a logistical possibility. Although the business development manager at the Sunshine Coast Council is not specifically aware of design-led innovation, his role entails collaborating and benchmarking internationally and within Australia.

Other council recycling/re-use initiatives include operating three re-cycling shops at their landfill sites where everything from furniture to sports equipment is sold to the public instead of buried in landfills. The program generates revenues of up to $\$ 1$ million a year and there are plans to open another one. This program offsets the council's current $\$ 47$ million annual waste management budget.

Like Townsville, the Sunshine Coast Council is also looking to better dispose of its recycled glass which comprises $37 \%$ of mixed recycling bin contents and is trucked $100 \mathrm{~km}$ to a processor in Brisbane where half of it is disposed in landfills and the rest used to make new beverage containers. The Sunshine Coast Council is currently conducting a feasibility study into converting recycled glass into sand which can be sold as pipe bedding or mixed in with asphalt in construction projects. The glass re-processing project would cost an estimated \$1.5 million and would save in transport costs and provide local employment.

The Sunshine Coast Council's business development manager sees the newly introduced statewide waste levy as a positive development giving recycling and re-use a matter of urgency. The Council also sends recyclables to China which is now rejecting contaminated waste. Additionally, this change is seen as opportunity to upgrade the recycling process to force better sorting of waste.

The Sunshine Coast Council is also part of the Australian product stewardship program (Australian Government, 2018) governing e-waste, where the cost of recycling is added to the price of the product. Mobile phones are an example of this program. The Sunshine Coast Council has installed mobile phone waste bins in public libraries. The mobile phones are sent to a processor who also pays the Council \$154 per tonne for old computers and printers, crushes them, segregates the parts and sells them offshore.

\section{Circular Projects at the Local University and Bottom-up Initiatives in North Queensland}

Universities are often viewed as thought leaders when it comes to researching and implementing innovative practices (Regional Australia Institute, 2015). They can drive bottom-up Circular Economy initiatives and become a resource for the wider business community (RUN, 2018). James Cook University (JCU) has a Townsville and Cairns campus. The university introduced a Waste Reduction Management Plan in 2015 (Estate Directorate, 2015) with a long-term target of reducing waste by $20 \%$ and recycling $70 \%$ of its waste by 2030 . JCU sends 700,000 kilograms of waste to landfills every year. A campaign called "War on Waste” saw various successful initiatives introduced, including the recycling of soft plastic, which is now deposited in extra bins on campus and is a highly successful program. The Townsville campus has begun collecting fresh 
food waste from campus vendors which is treated by the local company VRM (the same the Townsville City Council is using) turning biowaste into fertiliser and compost.

In 2017 JCU introduced Warp-It, a furniture re-use system (originated in the UK), that straddles the sharing economy concept being pushed by the Circular Economy. Staff can offer unwanted furniture which is picked up and re-used by other employees of the university, avoiding dumping the furniture into landfills. 12.1 tonnes of unused furniture have been saved so far from landfills (22 March 2019, https://au.getwarpit.com/company/jcu) and are now part of the "shared economy” where product lifespans are extended.

The environmental and operation manager at JCU, who is highly knowledgeable about Circular Economy practices and has initiated most of the existing sustainability projects, identifies the silo-mentality of academic departments as the biggest barrier to make use of design-led innovation techniques. The campus operations manager knows about various sustainability programs being developed in different departments but sees no cross-disciplinary or interdepartmental collaboration happening. There is an absence of the use of Design Thinking, Co-creation or other collaborative methods common to design-led innovation on a campus-wide basis.

Various Circular Economy-type initiatives driven by individuals (bottom-up) have been recorded in the region which include creating jewellery out of broken bicycle tubes (up-cycling waste into wearable items) and Food Rescue which collects leftover food at the end of business day and redistributes edible surplus food to prevent its unnecessary waste and support vulnerable people in the community.

\section{Circular Projects at the Local University in Southeast Queensland}

Like JCU, the University of the Sunshine Coast (USC) lists "sustainability" as one of its top priorities and aims at zero net emission by 2025 (USC, 2017). The USC campus is located within the Sunshine Coast Regional Council area and has adapted its waste management practices to a growing student population. The operations manager for USC has the authority to negotiate contracts with on-campus food and beverage vendors who must use organically recyclable cutlery, napkins and paper plates. However, fast food franchises around the campus are creating new waste management problems, such as the appearance of pizza boxes, plastic straws and plastic bags containing food that are being discarded on the campus. The campus waste manager is now considering working with outside retailers to control the landfill-bound waste now being discarded on the campus.

The compostable waste collected in bins at campus is put into an onsite composter which is currently operating at full capacity. The compost is given away for free. Research is also being conducted into securing excess compost capacity with a large shopping centre nearby that turns vegetable matter into compost used by local strawberry growers.

USC's operations manager, who is not familiar with the term "design-led innovation", is also focused on community engagement as a core operating principle. That principle has translated into exploring ways to reduce carbon emissions through a ride-sharing app "Lift-and Go" that has just been introduced to students and staff. The use of the app is also being explored by an adjacent national insurance business.

The limiting factors that have been identified in expanding the waste management program are the campus wide resources needed to ensure its obligations to reduce carbon emissions mandated 
by the state as well as lock-in waste disposal contracts with the Sunshine Coast Council. Also identified are the numerous campus environmental groups who do not communicate with each other about their agendas, an area that would be facilitated by a design-led innovation process.

\section{The Circular Experiment in Ocean Street SME’s: Bottom-up Initiative in Southeast Queensland}

A project solely focused on implementing Circular Economy practices was completed in southeast Queensland in December 2017. "The Circular Experiment”

(www.thecircularexperiment.com) was a pilot program launched in Maroochydore on the

Sunshine Coast in Queensland. The founders of the project said they focused on introducing Circular Economy practices such as servitisation, asset swapping and waste reduction to small businesses on Ocean Street, which has a high concentration of 56 businesses covering 19 hospitality operators, 6 retail outlets, and 31 service providers. The project coordinators had the goal of making business owners aware of practices that could save energy, reduce organic waste, encourage recycling, and use unoccupied office space.

On a small scale, Circular Economy initiatives are driven by building positive relationships with local businesses, creating good customer relations and marketing opportunities, and cutting back on waste. However, as the project developers found, there was resistance to the idea when they first started talking with Ocean Street business owners. Most business owners were time poor, none had heard of the Circular Economy and the owners who expressed interest wanted concrete examples of where it was working in Australia. The experiment organisers said of the 56 businesses they approached, forty-five participated in the experiment only after face-to-face meetings.

Resource efficiency was one of the primary Circular Economy concepts pitched by the project. However, the main motivation for participating businesses was reportedly to promote an "ecofriendly” message, which would in turn attract more customers.

After the project ended, no data evaluating success was made available. As a consequence, follow-up interviews were conducted with four of the experiment participants (food-and-beverage businesses) to gain insights into their experience and get a sense of its success to motivate ongoing Circular Economy practices.

The follow-up interviews revealed that one of the key waste management practices put in place-a composting program-was abandoned because of logistical issues; another because of faulty equipment. For example, a vegetarian restaurant stopped its composting waste bin because no one picked up the compost. One of the employees at the restaurant had been using the compost on his farm but had moved and the program stopped after he left.

At a popular bar, a glass crushing machine used to grind hundreds of bottles of beer to save space in a recycling waste bin stopped working after a week. The manager of the bar at the time said the equipment servicing was not reliable so the machine was removed. However, he also reported that a detailed analysis of the bar's electricity use was helpful in planning better ways to use the refrigeration system.

The owner of two nightclubs and bars on Ocean Street reported that he still continues to dispose of his coffee grounds, which continue to be picked up by a third party to be used as a soil amendment; the owner also stopped offering customers plastic straws because of the experiment, 
which helped his staff deal with upset customers by pointing out that plastic straws can kill marine life.

All who were interviewed agreed that the Circular Experiment at the very least raised awareness among staff about waste management and recycling issues and allowed them to operate as "green business" for marketing purposes. The Sunshine Coast Council provided a cigarette butt bin for use in the Circular Experiment but reported no meaningful data about its efficacy in reducing cigarette litter on Ocean Street.

Design-led innovation did not play a role in the experiment, although the project developers told researchers they would have liked to implement Design Thinking and design-led innovation practices. However, there was no direct collaboration among the businesses participating in the experiment-partly because there was no place to workshop. Overall, business owners were focused on immediate improvements and staffing issues. Any additional engagement such as cocreative idea development appeared to be too time consuming for business owners who were concerned about running day-to-day operations.

\section{Conclusion and Outlook}

The goal of the Circular Economy is to achieve a sustainable economic future that reduces waste, increases product reliability, and preserves natural resources. Waste managers in regional Queensland are positioned to take a leadership role in introducing and executing Circular Economy principles. A series of interviews revealed a growing awareness among waste managers in regional Queensland of the need to seek innovative ways to reduce waste given political and economic pressures.

Policy changes play a critical role in the implementation of Circular Economy development in regional centres. In Queensland, for example, the re-introduction of the waste levy will tax all state councils, including Townsville, Cairns and the Sunshine Coast for general waste stream disposal into landfills. The Sunshine Coast Council's business development manager called the state wide levy a 'polluter pay' strategy that will make waste mitigation a 'priority' because it raises the costs of using landfills.

China's new standards reducing contamination in recycled waste means that local councils also have to develop new ways to lower waste stream contamination if their contract suppliers want to still do business with China or develop other plans to re-use and recycle waste on a local level.

Overall, interviews confirmed a political will to invest in new technologies but little current funding to finance pilot programs. Design-led innovation has a role to play in that process, but it is not yet used as a consistent framework to implement Circular Economy strategies. There is little understanding about the opportunities design-led innovation can offer or how it could be used. However, waste managers liaise with stakeholders such as local businesses to reduce waste; but efforts to create new markets for waste are subject to the vagaries of policy and governmental initiatives.

Circular Economy initiatives involving small businesses attempted by the Circular Experiment revealed the problem of inconsistent engagement as a major impediment to ongoing practices. Businesses participating in the experiment did not follow through on several of the experimental initiatives because their logistical supply chain collapsed, there was no ongoing government incentive to continue and initiators did not follow through with meetings or reports that would show areas of improvement or successful outcomes. For small businesses, most said the benefit of 
the Circular Experiment was to increase awareness among employees about how to better manage their waste and to market themselves as a "green business". A design-led innovation process had the potential to expand the experiment but was never used as a way to achieve iterative solutions.

Waste managers at local councils and the universities in this study demonstrated a strong awareness about Circular Economy principles, which they are putting into practice on a limited basis; but local business owners had few ideas about how the Circular Economy works. There was also a lack of state wide or local leadership in visualizing and demonstrating how the transition to a Circular Economy can be achieved with concrete plans. The intersection of state policy, local council budgets and shifting international markets are governing the practices and business decisions of local waste managers in Queensland, Australia. This is particularly true in regional North Queensland, which copes with long distances to large scale re-use and re-cycling markets in the state capital, Brisbane. Geographical isolation plays an important role in how local councils re-purpose their waste into useable products. There is evidence the transition to Circular Economy practices is beginning to happen but in an ad hoc way.

Design-led innovation using methods like Design Thinking, Service Design Thinking and Cocreation can help bridge that knowledge gap with a systematic approach to problem solving employing iterative and collaborative processes needed for idea generation across different disciplines and school of thoughts. One immediate way to improve awareness how design-led innovation can help the transition to a Circular Economy could be done by promoting the use of design-led innovation tools that are readily available on the Internet. These tools, which are often decision matrices, help stakeholders visualize and map a way forward to test the viability of Circular Economy practices. Specifically, regional waste managers and local councils could be introduced to the often complex mapping exercises that help translate the Circular Economy waste hierarchy in an accessible model; case-studies would further clarify and identify partnerships between councils and industry that can work together to implement Circular Economy practices.

Local councils could also hire design consultancies to help solve pressing problems in the region using Denmark as a model where the government-funded Design Centre uses Co-creation in regional centres to solve complex social and economic issues in a collaborative process (Cheng, 2019). In regional Queensland, funding from the local government would need to be made available to kick-start the development of a design-led innovation culture similar to Denmark. That would include offering training, lectures and workshops to raise awareness and to help businesses understand the value in implementing Circular Economy practices.

Regional centres in Australia could open Circular Economy Opportunity Labs, which is done in Italy, for example. The Italian National Strategy for Inland Areas promotes 'the creation of hubs in rural areas' which are participatory platforms that are 'based on the principles of open source technologies, social inclusion, mass collaboration, openness, sharing and global action’ (Salvia, Andreopoulou and Quaranta, 2018:8). Despite many regional areas facing additional challenges due to their geographic isolation and less developed innovation capacity, there are ample opportunities for regional Queensland-and Australian regional areas in general-to embrace design-led innovation to help implement Circular Economy practices.

\section{References}

Andrews D (2015) The circular economy, design thinking and education for sustainability. Local Economy 30(3): 305-315 
Armitage C (2017) 'We need to significantly lift our game': Australia is not the innovation nation we like to think it is. The Sydney Morning Herald, 10 February. Available at:

https://www.smh.com.au/business/companies/we-need-to-significantly-lift-our-gameaustralia-is-not-the-innovation-nation-we-like-to-think-it-is-20170201-gu2x5b.html (accessed 31 May 2019).

Australian Department of Industry, Innovation and Science (2016). Available at: https://archive.industry.gov.au/industry/IndustrySectors/AdvancedManufacturing/Pages/default.aspx (accessed 31 May 2019).

Australian Government. (2018) Product stewardship. Available at: https://www.environment.gov.au/protection/waste-resource-recovery/product-stewardship (accessed 31 May 2019)

Australia Post (2017) Transitioning to a Circular Economy: Insights from the frontline

Australian Water Association (2016) Victoria launches new grants for waste-to-energy.

Barbero S and Bicocca M (2017) Systemic design approach in policy-making for sustainable territorial development. The Design Journal 20(1): S3496-S3506.

Berg P, Pihlajamaa J, Hansen PK, et al. (2016) Measurement of Design Front End: Radical Innovation Approach. In: Brenner W and Uebernickel F (eds) Design Thinking for Innovation: Research and Practice. Schwitzerland: Springer, 41-56.

Braw E (2014) Five countries moving ahead of the pack on circular economy legislation. The Guardian.

Brown T (2009) Change by Design: How Design Thinking Transforms Organizations and Inspires Innovation, New York: HarperCollins.

Bucolo S, Wrigley C and Matthews J (2012) Gaps in organisational leadership: Linking strategic and operational activities through design-led propositions. Design Management Journal $7(1): 18-28$.

Bucolo S and Wrigley C (2014) Design-led innovation: Overcoming challenges to designing competitiveness to succeed in high cost environments. In: Ross G and Kennedy N (eds) Global perspectives on achieving success in high and low cost operating environments. IGI Global, 241-251.

Caldwell F (2018) Waste levy announced for Queensland to stem interstate dumping. Brisbane Times, 1 June. Available at: https://www.brisbanetimes.com.au/politics/queensland/wastelevy-announced-for-queensland-to-stem-interstate-dumping-20180601-p4ziv3.html (accessed 31 May 2019).

Cairns Regional Council (2018) Waste Reduction and Recycling Strategy 2018-2027. Available at: https://www.cairns.qld.gov.au/_data/assets/pdf_file/0019/14365/Strategy.pdf (accessed 31 May 2019).

Cairns Regional Council (2010) Waste Management Strategy 2010-2015. Available at: https://www.cairns.qld.gov.au/_data/assets/pdf_file/0018/14373/ActionPlan.pdf (accessed 31 May 2019).

Ceschin F and Gaziulusoy I (2016) Evolution of design for sustainability: From product design to design for system innovations and transitions. Design Studies 47: 118-163.

Chang C (2018) China's ban on foreign waste set to impact Australia. News.com.au.

Cheng L (2019) Design thinking and regional cities: Christian Bason. ArchitectureAU. Available at: https://architectureau.com/articles/design-thinking-and-regional-cities-christian-bason/

Circle Economy (2019) The Circularity Gap Report 2019.

City of Melbourne (2015) New bin sensors to reduce waste overflow.

Cole R (2017) Increased China 0.5 per cent contamination limit a 'very challenging target'. Available at: https://resource.co/article/increased-china-05-cent-contamination-limit-verychallenging-target-12253.

Collett J (2018) More Australians boost their income through the sharing economy. The Sydney Morning Herald, 1 May. Available at: https://www.smh.com.au/money/planning-and- 
budgeting/more-australians-boost-their-income-through-the-sharing-economy-20180427p4zc25.html (accessed 31 May 2019).

Commission of the European Communities (2009) Design as a driver of user-centred innovation.

Coronado D, Acosta M and Ferñandez A. (2008) Attitudes to innovation in peripheral economic regions. Research Policy 37: 1009-1021.

Dayton L and Green R (2018) No clear target in Australia's 2030 national innovation report. The Conversation. (accessed 12 September 2018).

den Hollander MC, Bakker CA and Hultink EJ (2017) Product Design in a Circular Economy. Journal of Industrial Ecology 21(3): 517-525.

Design Council (2011) Design for Innovation: Facts, figures and practical plans for growth.

Design Council (2015) Leading Business by Design: High value manufacturing.

DesignSingapore Council (2016) Design 2025: Design Master Plan.

Ellen MacArthur Foundation (2013) Designing for a Circular Economy - The conceptual design of a circular mobile device. Available at:

https://www.townsville.qld.gov.au/_data/assets/pdf_file/0025/5884/NQ-Regional-WasteReduction-and-Recycling-Plan.pdf.

Ellen MacArthur Foundation (2015a) Towards a Circular Economy: Economic and Business Rational for an Accelerated Transition.

Ellen MacArthur Foundation (2015b) Delivering the Circular Economy: A toolkit for policymakers. Available at:

www.ellenmacarthurfoundation.org/assets/downloads/publications/EllenMacArthurFoundati on_PolicymakerToolkit.pdf (accessed 31 May 2019).

embark (2016) Clean Cowra NSW.

EPA NSW (2018) Response to the enforcement of the China National Sword Policy. (accessed 13 September 2018).

Estate Directorate (2015) Waste Reduction Management Plan. Available at: https://www.jcu.edu.au/_data/assets/pdf_file/0005/192434/Waste-ReductionManagement-Plan-v1.pdf (accessed 31 May 2019).

European Commission (2012) Manifesto for a resource-efficient Europe. Available at: http://europa.eu/rapid/press-release_MEMO-12-989_en.htm.

European Commission (2016) EU Waste Legislation. Available at: http://ec.europa.eu/environment/waste/legislation/a.htm.

European Environment Agency (2017) Circular by design: Products in the circular economy.

Evans J, Bocken D and University of Cambridge \& Institute for Manufacturing (2013) Circular Economy Toolkit - Resources for an Evolving World. Available at: www.CircularEconomyToolkit.com.

Fleischmann K (2013) Social entrepreneurs and social designers: Change makers with a new mindset? International Journal of Business and Social Science 4(16): 9-17.

Fleischmann K, Hielscher S and Merritt T (2016) Making things in Fab Labs: a case study on sustainability and co-creation. Digital Creativity 27(2): 113-131.

Fleischmann K, Daniel R and Welters R (2017) Developing a regional economy through creative industries: Innovation capacity in a regional Australian city. Creative Industries Journal.

Forum for the Future (2016) Unilever and Forum for the Future launched Circular economy business model toolkit. Available at: http://recyclingportal.eu/Archive/21018.

Gardien P, Rincker M and Deckers E (2016) Designing for the Knowledge Economy: Accelerating Breakthrough Innovation Through Cocreation. The Design Journal 19(2): 283299.

Gerholdt J (2015) The 5 business models that put the circular economy to work. GreenBiz. (accessed 14 September 2018).

Global Innovation Index (2018) Global Innovation Index 2018 - Energizing the World with Innovation. 
Goldsworthy K (2017) The Speedcycle: a design-led framework for fast and slow circular fashion lifecycles. The Design Journal 20(1): S1960-S1970.

Green Industries South Australia (2017) Benefits of a Circular Economy in South Australia Summary.

Gulari MN, Melioranski R-H, Er O, et al. (2017) THE FUTURE OF DESIGN SUPPORT: What Can We Learn From Design Support Experience in the UK, Estonia and Turkey? Design for Next, 12th EAD Conference. Sapienza University of Rome, 1-12.

Jacobs (2015) A Bio-energy Roadmap for South Australia, RENEWABLES SA - Jacobs Report. Jacobs Group (Australia) Pty Limited.

Jambeck JR, Geyer R, Wilcox C, et al. (2015) Plastic waste inputs from land into the ocean. Science 347(6223): 768-771.

Kalmykova Y, Sadagopan M and Rosado L (2018) Circular economy - From review of theories and practices to development of implementation tools. Resources, Conservation \& Recycling 135: 190-201.

Kane G (2016) Designing a product-service for repair \& maintenance of medical imaging equipment in Africa. Faculty of Industrial Design Engineering. Delft University of Technology.

Lasker P and Goloubeva J (2018) Australia needs to start recycling and reusing its own waste, says industry struggling under China’s ban. ABC News, 15 April. Available at: http://www.abc.net.au/news/2018-04-15/australia-tossing-up-circular-approach-to-itswaste/9657342 (accessed 31 May 2019).

Lee YN (2018) The world is scrambling now that China is refusing to be a trash dumping ground. NCNBC, 16 April. Available at: https://www.cnbc.com/2018/04/16/climate-change-chinabans-import-of-foreign-waste-to-stop-pollution.html (accessed 31 May 2019).

Liedtke J and Ogilvie T (2011) Designing for Growth: A Design Thinking Tool Kit for Managers New York, Chichester, West Sussex: Columbia University Press.

Marchese F (2017) How Sicilian oranges are being made into clothes. BBC News ,24 August. Available at: https://www.bbc.com/news/business-40946159 (accessed 31 May 2019).

Mestre A and Cooper T (2017) Circular Product Design. A Multiple Loops Life Cycle Design Approach for the Circular Economy. The Design Journal 20(1): S1620-S1635.

Moorhouse D and Moorhouse D (2017) Sustainable Design: Circular Economy in Fashion and Textiles. The Design Journal 20(1): 1948-1959.

Northern Rivers Waste (2018) BIOCYCLE COMPOST: OUR BIOCYCLE COMPOST IS MAGIC FOR YOUR GARDEN.

Palmer C, Shilton D, Jeyaratnam E, et al. (2015) Australia's innovation problem explained in 10 charts. The Conversation. (accessed 12 September 2018).

Parker L 2018 China's ban on trash imports shifts waste crisis to Southeast Asia, National Geographic, Available at $<$ https://www.nationalgeographic.com/environment/2018/11/china-ban-plastic-trashimports-shifts-waste-crisis-southeast-asia-malaysia/> .

Philips Lighting (2015) Lighting up the National Union of Students Office.

Prendeville S, Cherim E and Bocken N (2018) Circular Cities: Mapping Six Cities in Transition. Environmental Innovation and Societal Transitions 26: 171-194.

Prendeville S and Bocken N. (2017) Sustainable Business Models through Service Design. 14th Global Conference on Sustainable Manufacturing. Stellenbosch, South Africa: Elsevier, 292-299.

Preston F (2012) A Global Redesign?: Shaping the Circular Economy: Chatham House London. Queensland Government (2018a) Transforming Queensland's Recycling and Waste Industry Direction Paper. 
Queensland Government (2018b) Plastic pollution reduction. Available at: https://www.qld.gov.au/environment/pollution/management/waste/reduction/plasticpollution.

Raulik G, Cawood G and Larsen P (2008) National Design Strategies and Country Competitive Economic Advantage. The Design Journal 11(2): 119-135.

Raulik-Murphy G (2010) A comparative analysis of strategies for design promotion in different national contexts. University of Wales Institute. Cardiff: University of Wales, 265.

Regional Australia Institute (2015) Innovation in Regional Australia: Spreading the Ideas Boom.

Reigado CR, da Costa Fernandes S, Saavedra YMB, et al. (2017) A Circular Economy Toolkit as an Alternative to Improve the Application of PSS Methodologies. Procedia CIRP 64: 37-42.

Rowley J (2002) Using Case Studies in Research. Management Research News 25(1): 16-27.

RSA - Action and Research Centre (2016) Designing for a circular economy: Lessons from The Great Recovery 2012 - 2016. Available at:

https://www.thersa.org/globalassets/pdfs/reports/the-great-recovery---designing-for-acircular-economy.pdf (accessed 31 May 2019).

RUN (2018) Regional Universities Network, Regional Strength, National Success. Available at: http://www.run.edu.au/.

Salvia R, Andreopoulou ZS and Quaranta G. (2018) The circular economy: A broader perspective for rural areas. Rivista di Studi sulla Sostenibilita 4(July): 1-14.

Sanders EB-N and Stappers PJ (2008) Co-creation and the new landscapes of design. CoDesign: International Journal of CoCreation in Design and the Arts 4(1): 5-18.

Simonchik A, Iriarte I, Hoveskog M, et al. (2015) Bridging service design tools and business model innovation (BMI) for servitization in B2B context. The Spring Servitization Conference (SSC 2015), Servitization: the theory and impact, 18-19 May 2015, Aston Business School, Aston University, UK. Aston Business School, UK.

Smith P, Baille J and McHattie L-S (2017) Sustainable Design Futures: An open design vision for the circular economy in fashion and textiles. The Design Journal 20(1): S1938-S1947.

Sunshine Coast Council (2014) Sunshine Coast waste strategy 2015-2025. Available at: https://www.sunshinecoast.qld.gov.au/Council/Planning-and-Projects/CouncilStrategies/Sunshine-Coast-Waste-Strategy (accessed 31 May 2019).

Sunshine Coast Council (2018) Regional Economy.

The Circular Design Guide (2017) Available at: https://www.circulardesignguide.com/.

The Circular Experiment (2018) Available at: https://www.thecircularexperiment.com/.

Townsville City Council (2014) NQ regional waste reduction \& recycling plan 2014-2024. Available at: https://www.townsville.qld.gov.au/_data/assets/pdf_file/0025/5884/NQRegional-Waste-Reduction-and-Recycling-Plan.pdf (accessed 31 May 2019).

Turnbull S and MacKenzie B (2017) Regional city of Lismore has answer to NSW glass recycling crisis. ABC News. 8 August. Available at: http://www.abc.net.au/news/2017-0808/lismore-glass-crisis-solution/8785696 (accessed 31 May 2019).

United Nations Economic Commission for Europe (UNECE) (2018) How can we make the circular economy a reality in the region?

USC (2017) A road map to zero net emissions by 2025. University of the Sunshine Coast.

UN Environment International Resource Panel (2019) Global Resource Outlook 2019.

Virtanen M, Manskinen K and Eerola S (2017) Circular Material Library. An Innovative Tool to Design Circular Economy. The Design Journal 20(1): S1611-S1619.

Wastling T, Charnley F and Moreno M (2018) Design for Circular Behaviour: Considering Users in a Circular Economy. Sustainability 10: 1-22.

West S and Di Nardo S (2016) Creating product-service system opportunities for small and medium size firms using service design tools. Procedia CIRP 47: 96-101.

White M (2015) Circular Economy to become \$26bn industry in Australia by 2025: World economic forum. The Sydney Morning Herald. Available at: 
http://www.smh.com.au/national/circular-economy-to-become-26bn-industry-in-australiaby-2025-world-economic-forum-20150630-gi19n3.html (accessed 31 May 2019).

WRAP and Green Alliance (2015) Employment and the Job creation in a more resource efficient Britain

Yin R, K (2009) Case study research: Design and methods, Thousand Oaks, CA: Sage.

ZeroWaste (2016) National Zero Waste Council Circular Economy Business Toolkit. Available at: www.nzwc.ca/Documents/CircularEconomyBusinessToolkit.pdf. 